\title{
Luminal Versus Non-luminal Breast Cancer CDH1 Immunohistochemical Expression
}

\author{
DANA CARMEN ZAHA ${ }^{1}$, CLAUDIA MARIA J URCA ${ }^{1}$, SIMONA BUNGAU ${ }^{1}$, GABRIELA CIOCA $^{2 *}$, AMORIN POPA*, CRISTIAN SAVA ${ }^{1}$, \\ LAURA ENDRES ${ }^{1}$, COSMIN MIHAI VESA ${ }^{1}$ \\ IUniversity of Oradea, Faculty of Medicine and Pharmacy, 101 Decembrie Sq., 410073, Oradea, Romania \\ ¿Lucian Blaga University of Sibiu, Faculty of Medicine, 10 Victoriei Blvd., 550024, Sibiu, Romania
}

\begin{abstract}
We investigated the immunohistochemical expression of E-cadherin (product of $\mathrm{CDH} 1$ gene) and its correlation with clinical-pathological parameters and survival rate in the molecular groups of breast cancer. Our study included female breast cancer patients diagnosed at the Municipal Emergency Clinical Hospital Timisoara followed up five years since diagnosis using formalin fixed paraffin embedded tissue. The traditional prognostic factors (age, tumor size, histological type, histological grade, anatomical status of the lymph nodes) were abstracted from histopathology reports and we set prognostic index (the Nothingham and lymph-node prognosis index). Molecular classification on selected cases was performed in agreement with data from the literature: Iuminal $A, B, H E R 2+$, triple-negative. We noted positive (membranar) expressions in 43 cases (70.49\%). Negative immunoreactions for E-cadherin have been observed in all cases of lobular carcinomas (4 cases), as well as 6 cases of mixed carcinomas. A significant correlation was found between E-cadherin expression and hormonal status, tumor size, histologic type, tumorgrade and molecular subtype. Most of the luminal $A$ and $B$ tumors were $E$-cadherin positive, while more than half of non-luminal tumors were $E$-cadherin negative. Survival rates are different in the negative and positive E-cadherin tumor groups respectively and between luminal and non-luminal groups. E-cadherin expression may be a useful prognostic marker for classifying other subgroups of breast cancer.
\end{abstract}

Keywords: CDH1, breast cancer, immunohistochemistry, E-Cadherin

The $\mathrm{CDH} 1$ gene is located on $16 q 22.1$, a region frequently affected by loss of heterozygosity in sporadic breast cancer, the product of the gene being a transmembrane cell adhesion molecule called E-cadherin. It is a glycoprotein that presents a large extracellular domain consisting of five repeat units that provide adhesion, a transmembrane domain, and an intracellular domain that interacts with the cytoskeleton protein actin in the protein attachment. The basic function of cadherins is mechanical adhesion between epithelial cells, but they also have important roles in establishing cell polarity, cell glandular differentiation, regulating morphogenesis; all these functions are necessary for the normal epithelial architecture [1].

Local invasion and metastasis of malignant tumors are complex processes that start with the disruption of normal cell-cell adhesion and detachment of malignant cells from the primary tumor; immunohistochemical analysis is essential, regardless of the type of cancer being investigated [2-5]. Tumor progression and metastasis are based on several successive stages including: separation of tumor cells from the primary tumor, attachment to the basal vascular membrane followed by its destruction and entering the blood and/or lymphatic circulation, leaving blood vessels and resettling in target organs as metastasis $[6,7]$. The tumour invasion and metastasis are the major causes of mortality in patients with breast cancer. Data from experimental models of carcinogenesis suggest that E-cadherin has a strong tumor suppressor effect in various cancers $[8,9]$.

Consistent with this role in the progression of breast cancer, the partial or total loss of CDH1 expression correlates with the poor prognosis of these patients. Mutations were found in the early stages of non-invasive carcinomas, thus associating CDH1 mutations with loss of control of cell growth. In general, ductal breast tumors show heterogeneously loss of E-cadherin expression. Loss of E-cadherin expression may result in a poorly differentiated tumor phenotype and this has been demonstrated in invasive lobular carcinoma of the breast, a less frequent breast cancer type.

The clinical-pathological parameters (tumor size, tumor grade, presence of tumor metastases etc.) and their conection with the immunohistochemical expression of E-cadherin have been studied together with the cases of survival in molecular groups of breast cancer.

\section{Experimental part}

\section{Materials and methods}

Our study included 61 female patients aged between 31 and 90 years old which were diagnosed between 20082013 at the Municipal Emergency Clinical Hospital Timisoara, and followed up for five years from diagnosis. The traditional prognostic factors included: age, tumor size, histological type, histological grade, clinical stage and anatomical status of the lymph nodes, all were abstracted from histopathology reports. Based on these parameters, we determined the Nothingham Prognostic Index (NPI) and Lymph-node Prognosis Index (LPI) as follows: $\mathrm{NPI}=0.2$ tumour size $(\mathrm{cm})+$ lymph-node stage $(1$, node negative; 2, 1-3 positive lymph nodes; $3, \geq 4$ positive lymph nodes) $+S B R$ grade (1, good; 2 , moderate; 3 , poor) and $L P I=$ tumour size $(\mathrm{cm})+1$ if $S B R$ grade 3 or $4(0$ otherwise) + $\log [$ (positive lymph nodes+0.5)/ (negative lymph nodes+0.5)]

$\mathrm{NPI}$ and LPI distributions were divided into quartiles [10]: -NPI was categorized into low (NPI<3.4), intermediate $(\mathrm{NPI}<4.2$ and $\mathrm{NPI}<4.8)$, and high risk (NPI $\leq 7.6)$;

-LPI: low $(\mathrm{LPI}<0.6)$, intermediate $(\mathrm{LPI}<1.5$ and $\mathrm{Lpi}<2.5)$ and high risk (LPI $\leq 10.3)$.

Molecular differences have been shown to correlate with clinical features, such as survival, prognosis and treatment 
sensitivity. Considering data from the literature [11-14], IHC technique was used to obtain molecular classification of the selected cases:

-luminal A (ER+ and/or PR+, HER2-),

-luminal B (ER+ and/orPR+, HER2+), HER2+/ER- (ER, PR-, HER2+),

-triple-negative (ER-, PR-, HER2-).

Histopathology was based on hematoxylin and eosin (H\&E) stained slides. Formalin fixed paraffin embedded tissue which had been stored at the patient was used for the immunohistochemical investigations. ER and PR were scored using the Allred scoring system and all cases with $10 \%$ positive cells were considered positive. HER2 was scored according to HercepTest criteria as follows: 0 - no staining or incomplete staining in $<10 \%$ cells, 1+ incomplete staining in $>10 \%$ cells, $2+$ - weak to moderate complete staining in $>10 \%$ cells, $3+$ - strong complete staining in $>10 \%$ cells. All cases with a score of $2+$ or $3+$ were considered HER 2 positive. The CK5/6 expression was interpreted as 0: no tumor cells stained; + 1: fewer than 10 $\%$ of tumor cells stained; $+2: 10-50 \%$ positive tumor cells; $+3:>50 \%$ of tumor cells stained. The expression was scored as positive $(>0)$ if any cytoplasmic or membranous staining of tumor cells were observed [15].

Anti-E-cadherin monoclonal antibody was used (clone $\mathrm{NCH}$-38, DakoCytomation, Denmark) by EnVision technique. For interpretation, only membranous staining of the malignant tissues was considered as positive and the scoring intensity was based on comparisons with normal control areas. The intensity of the membrane reactivity was scored semiquantitatively on a scale as follows: 0: lack of staining or membrane positivity in $<10$ $\%$ of tumor cells; 1 incomplete and weak membranous staining in $10 \%$ of tumor cells; 2 : complete membranous staining, with weak or moderate intensity in $>10 \%$ of tumor cells; 3: strong membranous staining in $>10 \%$ of tumor cells. According to this score, the reaction was considered as negative for scores of 0 and 1 , and positive for score 2 and 3. Cytoplasmic staining was considered nonspecific and not included in the assessment [16].

The research was conducted in accordance with the WMA Declaration of Ethical Helsinki - Medical Research Involving Human Principles for Subjects and was approved by the Ethic Commission of the Council of Medicine and Pharmacy Faculty, University of Oradea, Oradea, Romania. The patients included in this study were notified about the study and they signed and informed consent. Statistical analysis (frequencies and percentages for qualitative variables, statistical comparison - chi square) of the results was performed by known criteria $(p<0.05$ significant differences). Kaplan-Meier method was used to assess survival.

\section{Results and discusions}

IHC results of the 61 cases showed positive in 43 (70.49 $\%)$ tumors, and negative membranous staining in all the studied lobular carcinomas. Table 1 shows the associations

\begin{tabular}{|c|c|c|c|c|c|}
\hline \multirow{2}{*}{\multicolumn{2}{|c|}{ Patients' characteristics }} & \multicolumn{4}{|c|}{ E-cadherin expression } \\
\hline & & \multirow{3}{*}{$\begin{array}{c}\text { Total } \\
61\end{array}$} & \multirow{3}{*}{$\begin{array}{c}\text { Negative } \\
\text { No (\%) } \\
18(29.5)\end{array}$} & \multirow{3}{*}{$\begin{array}{c}\text { Positive } \\
\text { No (\%) } \\
43(70.49)\end{array}$} & \multirow{3}{*}{ p } \\
\hline & & & & & \\
\hline Number of cases & & & & & \\
\hline \multirow{2}{*}{ Age (years) } & Under 56 & 26 & 7 & 19 & \multirow{2}{*}{0.7} \\
\hline & Over 56 & 35 & 11 & 24 & \\
\hline \multirow[t]{2}{*}{ Hormonal status } & Premenopausal & 27 & 15 & 12 & \multirow{2}{*}{0.00} \\
\hline & Postmenopausal & 34 & 3 & 31 & \\
\hline \multirow[t]{3}{*}{ Tumor size $(\mathrm{cm})$} & $\approx 2$ & 8 & 1 & 7 & \multirow{3}{*}{0.00} \\
\hline & $2.0-5.0$ & 34 & 4 & 30 & \\
\hline & 75 & 19 & 13 & 6 & \\
\hline \multirow{4}{*}{ Histologic type } & Ductal & 42 & 6 & 36 & \multirow{4}{*}{0.00} \\
\hline & Lobular & 4 & 4 & 0 & \\
\hline & $\begin{array}{l}\text { Mix (ductal and } \\
\text { lobular) }\end{array}$ & 9 & 6 & 3 & \\
\hline & Other & 6 & 2 & 4 & \\
\hline \multirow{3}{*}{ Tumor grade } & low & 4 & 0 & 4 & \multirow{3}{*}{0.00} \\
\hline & medium & 44 & 7 & 37 & \\
\hline & high & 13 & 11 & 2 & \\
\hline \multirow[t]{2}{*}{ Lymph node involvement } & absent & 18 & 4 & 14 & \multirow[b]{2}{*}{0.42} \\
\hline & present & 43 & 14 & 29 & \\
\hline \multirow[t]{2}{*}{ Stage } & $0, \mathrm{I}, \mathrm{II}$ & 39 & 11 & 28 & \multirow{2}{*}{0.77} \\
\hline & III, IV & 22 & 7 & 15 & \\
\hline \multirow{4}{*}{ Molecular subtype } & Luminal A & 26 & 3 & 23 & \multirow{4}{*}{0.00} \\
\hline & Luminal B & 15 & 1 & 14 & \\
\hline & Triple negative & 18 & 12 & 6 & \\
\hline & HER-2 & 2 & 2 & 0 & \\
\hline \multirow{3}{*}{$\begin{array}{l}\text { Prognostic Nothingham Index } \\
\text { (NPI) }\end{array}$} & Low & 22 & 3 & 19 & \multirow{3}{*}{0.004} \\
\hline & Intermediate & 31 & 9 & 22 & \\
\hline & High & 8 & 6 & 2 & \\
\hline \multirow{3}{*}{$\begin{array}{l}\text { Lympho-nodal prognostic index } \\
\text { (LPI) }\end{array}$} & Low & 18 & 3 & 15 & \multirow{3}{*}{0.01} \\
\hline & Intermediate & 30 & 7 & 23 & \\
\hline & High & 13 & 8 & 5 & \\
\hline \multicolumn{2}{|l|}{ 5-years relative survival rates } & & $58.80 \%$ & $75.60 \%$ & \\
\hline
\end{tabular}

Table 1

THE

RELATIONSHIP

BETWEEN

E-CADHERIN EXPRESSION AND PATIENTS' CHARACTERISTICS 
between E-cadherin expression and the different clinicopathological variables of the patients.

Significant associations were found between E-cadherin expression and hormonal status, tumor size, histologic type, tumor grade, molecular subtype and both Nothingham prognostic index and lympho-nodal prognostic index. Assessing the E-cadherin expression according to the molecular classification, we observed that luminal A type tumors formed the majority, expressing this marker at a rate of 23 out of $26(88.46 \%)$, the luminal B 14 out of 15 cases (93.33\%) and all HER-2 (2 cases) were negative. Triple negative subtype showed no expression in 12 of 18 cases $(66.66 \%)$.

The evaluation of cases with anti-E-cadherin antibodies has shown that luminal tumors have a clear predominance of expression cases, whereas in the non-luminal tumor group the majority were non-expression cases (table 2).
Considering menopausal status, most premenopausal cases have a negative reaction for E-cadherin (15 of 27) and they were considered in the non-luminal group, while most of postmenopausal cases were positive (31 of 34). Among the latter, 27 of 34 were luminal tumors.

The average tumor size was 3.65 (range 0.9 to $9.3 \mathrm{~cm}$ ). There is a trend for decreased expression of E-cadherin with an increase in tumor size. Most tumors having a diameter of less than $2 \mathrm{~cm}$ belong to positive E-cadherin luminal tumors (fig. 1). Most cases were invasive ductal carcinomas (68.85\%), 4 cases were invasive lobular carcinomas, 9 cases were mix type (ductal and lobular) and 6 cases were other types (medullary, tubular, mucinous, apocrine). The absence of membranous Ecadherin expression in invasive lobular carcinomas may determine the morphological features such as the characteristic cellular arrangement of lobular carcinoma

\begin{tabular}{|c|c|c|c|c|c|c|}
\hline \multirow[b]{2}{*}{ Parameter } & \multicolumn{2}{|c|}{$\begin{array}{c}\text { LUMINAL } \\
(\mathrm{n}=41)\end{array}$} & \multirow[b]{2}{*}{$\mathbf{p}$} & \multicolumn{2}{|c|}{ NON-LUMINAL $(\mathrm{n}=20)$} & \multirow[b]{2}{*}{$\mathbf{p}$} \\
\hline & $\begin{array}{c}\text { E-cadherin } \\
\text { positiv } \\
(\mathrm{n}=37)\end{array}$ & $\begin{array}{c}\text { E-cadherin } \\
\text { negativ } \\
(\mathrm{n}=4)\end{array}$ & & $\begin{array}{c}\text { E-cadherin } \\
\text { positiv } \\
(\mathrm{n}=6)\end{array}$ & $\begin{array}{c}\text { E-cadherin } \\
\text { negativ } \\
(n=14)\end{array}$ & \\
\hline \multicolumn{7}{|l|}{ Age (years) } \\
\hline Less than 56 & 15 & 1 & \multirow{2}{*}{0.54} & 4 & 6 & \multirow{2}{*}{0.33} \\
\hline More than 56 & 22 & 3 & & 2 & 8 & \\
\hline \multicolumn{7}{|l|}{ Hormonal status } \\
\hline Premenopausal & 10 & 1 & \multirow{2}{*}{0.92} & 2 & 14 & \multirow{2}{*}{0.00} \\
\hline Menopausal & 27 & 3 & & 4 & 0 & \\
\hline \multicolumn{7}{|l|}{ Tumor size $(\mathrm{cm})$} \\
\hline$<2$ & 5 & 0 & \multirow{3}{*}{0.16} & 2 & 1 & \multirow{3}{*}{0.03} \\
\hline 2 to 5 & 27 & 2 & & 3 & 2 & \\
\hline$>5$ & 5 & 2 & & 1 & 11 & \\
\hline \multicolumn{7}{|l|}{ Tumor grade } \\
\hline Low & 3 & 0 & \multirow{3}{*}{0.13} & 1 & 0 & \multirow{3}{*}{0.04} \\
\hline Medium & 33 & 3 & & 4 & 4 & \\
\hline High & 1 & 1 & & 1 & 10 & \\
\hline \multicolumn{7}{|l|}{ Histologic type } \\
\hline Ductal & 33 & 0 & \multirow{4}{*}{0.00} & 3 & 6 & \multirow{4}{*}{ - } \\
\hline Lobular & 0 & 4 & & 0 & 0 & \\
\hline Mix & 2 & 0 & & 1 & 6 & \\
\hline Other & 2 & 0 & & 2 & 2 & \\
\hline \multicolumn{7}{|c|}{ Lymph node involvement } \\
\hline Absent & 11 & 1 & \multirow{2}{*}{0.84} & 3 & 3 & \multirow{2}{*}{0.20} \\
\hline Present & 26 & 3 & & 3 & 11 & \\
\hline \multicolumn{7}{|l|}{ Stage } \\
\hline $0, \mathrm{I}, \mathrm{II}$ & 26 & 3 & \multirow{2}{*}{0.84} & 2 & 8 & \multirow{2}{*}{0.33} \\
\hline II, III & 11 & 1 & & 4 & 6 & \\
\hline \multicolumn{7}{|c|}{ Prognostic Nothingham (NPI) index } \\
\hline Low & 18 & 0 & \multirow{3}{*}{0.04} & 1 & 3 & \\
\hline Intermediate & 18 & 3 & & 4 & 6 & 0.59 \\
\hline High & 1 & 1 & & 1 & 5 & \\
\hline Lympho-nodal pr & index (LPI) & & & & & \\
\hline Low & 12 & 1 & & 3 & 2 & \\
\hline Intermediate & 21 & 2 & 0.71 & 2 & 5 & 0.19 \\
\hline High & 4 & 1 & & 1 & 7 & \\
\hline $\begin{array}{l}\text { 5-years relative } \\
\text { survival rates }\end{array}$ & & $93 \%$ & & & $83.70 \%$ & \\
\hline
\end{tabular}

Table 2

E- CADHERIN EXPRESSION IN LUMINAL AND NONLUMINAL TUMORS 

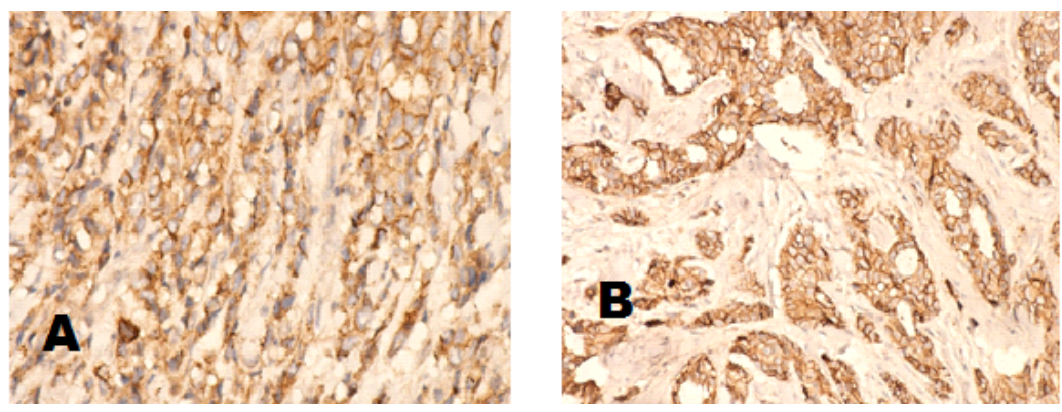

Fig.1. A - Invasive lobular/ductal carcinoma. E-cadherin immunoreaction (x40); B - Invasive ductal carcinoma. Positive E-cadherin immunoreaction with membrane pattern (x 20) cells. E-cadherin negative immunoreactions were observed in all cases of lobular carcinomas, as well as in six of nine of the mixed carcinomas. Invasive ductal carcinoma exhibited E-cadherin expression in 36 of 61 of luminal and non-luminal cases.

Most of the cases (72.13\%) showed a moderate degree of differentiation (G2), followed by poor differentiated cases (G3). There is a strong correlation between tumor grade and E-cadherin expression. Also, most of well differentiated infiltrating ductal carcinomas (G1) and 80.48 $\%$ of moderately differentiated tumors (G2) were luminal E-cadherin positive. G3 poorly differentiated carcinomas did not show expression for E-caderin (11 of 13) and most of them are included in the non-luminal group.

Tumors with low level of E-cadherin or absentexpression have a higher ability to invade lymph nodes. A high proportion of the cases showed lymph node metastases from tumor diagnosis. In our study, 14 of $18 \mathrm{E}$-cadherin negative tumors presented lymph node involvement at diagnosis, while Ecadherin positive in 29 of 43, although the statistical threshold has not been reached. Prognostic indices (NPI, LPI) have shown statistical significance when we compared E-cadherin expression for the entire group and for the luminal one. While non-expressing tumors have predominantly intermediate and higher prognostic Nothingham index risk (15 of 18), positive expression for E-cadherin cases was particularly favorable (low risk) for 19 of 43 cases.

The 5-year survival rates revealed the prognostic role of the immunohistochemical expression of E-cadherin demonstrated by the following values for the two categories of patients:

- tumors that expressed E-cadherin showed a 5-year survival rate of $75.6 \%$, the average survival time being 84 months;

- negative E-cadherin expression carcinomas showed a 5 -year survival rate of $68.8 \%$, the average survival time being 62 months.

The different pattern of E-cadherin expression in invasive ductal and lobular carcinomas suggests that this protein may play different roles in the development of each specific type of tumor. In addition, reducing the cadherin membrane expression in breast cancer is important in the mechanism of primary tumor dissemination.

In our analysis of patients with breast cancer, we found a rate of E-cadherin expression loss in 18 out of $61(29.5 \%)$, 14 out of 20 in non-luminal group (70\%) compared with luminal group, 4 out of $41(9.75 \%)$. Assessment of apoptosis by Bcl-2The predominant histological type was infiltrating ductal carcinoma E-cadherin positive. Data from the literature show that there is a wide variation of E-cadherin expression in invasive ductal carcinoma. This could be explained by different patients' population, number of cases, and variation of techniques or evaluation of expression. This study revealed that only membranous staining of E-cadherin was considered and identified 36 of 42 cases of invasive ductal carcinoma, more than those presented by Kowalski etal. and less than those presented in the study of J iang-Bo Liu etal. [17,18]. All cases of invasive lobular carcinomas were negative. In our study, 6 out of 42 pure invasive ductal carcinomas cases had negative expression, progressing and developing distant metastases. There were two cases of invasive papillary carcinoma that showed no expression of E-cadherin. In the mixed carcinomas we observed a mixed pattern of staining, the absence of expression in the areas of lobular differentiation with membranous expression in areas of ductal differentiation. By comparing luminal and nonluminal tumors, we noticed statistically significant differences in E-cadherin expression in the luminal group.

Tumors with reduced E-cadherin expression are poorly differentiated and have higher lymphoid metastasis capacity strongly related to overall survival. Heimann et al. showed that the percentage of tumors without expression of E-cadherin increased from GI to G3 [19]. However, other authors have shown that there is no correlation between the tumor grade and the expression of this marker. In our study, negative expression was significantly found in high grade $\mathrm{G} 3$ tumors, but no difference in the luminal and nonluminal group. Among non-luminal group G3 tumors were mostly E-cadherin negative.

$\mathrm{CDH} 1$ is considered as suppressor gene and in our study, we found no association between its expression and lymph node involvement for the entire studied group after comparing luminal and non-luminal groups. We could not detect any association of E-cadherin expression with age, clinical stage and lymph node involvement. Regarding terms of tumor size, the literature data is controversial; some studies showed that as the tumor size increases, the percentage of those with poor E-cadherin reaction increases, while others observed the persistence of $E$ cadherin expression even in large size tumors.

We found a correlation of E-cadherin expression with the Nothingham prognostic index and the lymphodal prognosis index in accordance with survival rates. However, it is worth mentioning that in this study, $29.5 \%$ of cases did not have lymph node metastasis and the percentage of tumors with E-cadherin expression was $77.78 \%$. Loss of E-cadherin expression has been associated with larger tumor size, higher tumor grade, lymph node metastasis in nonluminal breast cancer and poor prognosis, confirming the results of other studies $[20,21]$.

\section{Conclusions}

We noticed a statistically significant difference in Ecadherin expression among molecular subtypes; when we compared luminal and non-luminal tumors, it was observed that E-cadherin expression is lost especially in those non-luminal. Our results confirm that E-cadherin expression was closely related to molecular subtypes and it can be used as predictor of invasion and metastasis. Luminal tumors were E-cadherin positive, postmenopausal, invasive ductal carcinomas with good prognosis. In 
contrast, non-luminal tumors were negative for E-cadherin, especially premenopausal, having large size and high tumor grade. The rates of survival differ for the negative and positive E-cadherin tumor groups and also for the luminal and non-luminal groups.

\section{References}

1.NOLLET, F., KOOLS, P., VAN ROY, F., J. Mol. Biol., 299, nr. 3, 2000, p. 551.

2.BRATU, O.G., MARCU, R.D., SOCEA, B., NEAGU, T.P., DIACONU, C.C., SCARNECIU, I., TURCU, F.L., RADAVOI, G.D., BRATILA, E., BERCEANU, C., SPINU, A.D., Rev. Chim.(Bucharest), 69, no. 7, 2018, p. 1813.

3.ENDRES, L., TIT, D.M., BUNGAU, S., CIOCA, G., ABDEL-DAIM, M., BUHAS, C., POP, O., SAVA, C., Rev. Chim.(Bucharest), 69, no. 12, 2018. In press

4.ENDRES, L., UIVAROSAN D., TIT, D. M., POP O., BUNGAU S., BUHAS C., Iran. J. Public Health, 47, nr. 4, 2018, p. 606

5.MEHEDINTU, C., ANTONOVICI, M., BRINDUSE, L., BRATILA, E., STANCULESCU, R., BERCEANU, C., BRATU, 0., PITURU, S., ONOFRIESCU, M., MATASARIU D.R., Rev. Chim.(Bucharest), 69, no. 3, 2018, p. 581.

6.PALLAG, A., ROSCA, E., TIT, D. M., MUTIU G., BUNGAU S. G., POP O. L., R. J. Morphol. Embriol., 56, nr. 3, 2015, p. 1103.

7.RADAVOI, G.D., PRICOP, C., JINGA, V., MATES, D., RADOI, V.E., JINGA, M., URSU, R.I., BRATU, O.G., MISCHIANU, D.L., IORDACHE, P. Rom. J. Morphol. Embriol., 57, nr. 2, 2016, p. 467.

8.BERX, G., CLETON-J ANSEN, A.M., NOLLET, F., DE LEEUW, W.J ., VAN DE VIJ VER, M., CORNELISSE, C., VAN ROY, F., EMBO J., 14, nr. 24, 1995, p. 6107.

9.SUN, A.K., INAMURA, K., YAMAUCHI, M. NISHIHARA, R., MIMA, K., SUKAWA, Y., TINGTING, LI, YASUNARI, M., MORIKAWA, T., FITZGERALD, K. C., FUCHS, C.S., WU, K., CHAN, A.T., ZHANG, X., OGINO, S., QIAN, Z. R., Br. J. Cancer, 114, nr. 2, 2016, p. 199.
10.ABRIAL, C., DURANDO, X., CHOLLET, P., TACCA, O., I. RAOELFILS I., MOURET-REYNIER, M., GIMBERGUES, P., PENAULT-LIORCA, F., J. Clin. Oncol, 26, nr. 15, 2008, p. 22146.

11.SORLIE, T., PEROU, C.M., TIBSHIRANI, R., Aas, T., GEISLER, S., JOHNSEN, H., HASTIE, T., EISEN, M.B., VAN DE RIJ N, M., JEFFREY, S.S., THORSEN, T., QUIST, H., MATESE, J.C., BROWN, P.O., BOTSTEIN, D., LONNING, P.E., BORRESEN-DALE, A.L., Proc. Natl. Acad. Sci. USA, 98, nr. 19, 2001, p. 10869.

12.PARKER, J.S., MULLINS, M., CHEANG, M.C., LEUNG, S., VODUC, D., VICKERY, T., DAVIES, S., FAURON, C., HE, X., HU, Z., QUACKENBUSH, J.F., STIJ LEMAN, I.J ., PALAZZO, J., MARRON, J.S., NOBEL, A.B., MARDIS, E., NIELSEN, T.O., ELLIS, M.J., PEROU, C.M., BERNARD, P.S., J. Clin. Oncol., 27, 2009, p. 1160.

13.ABD EL-REHIM, D.M., BALL, G, PINDER, S.E., RAKHA, E., PAISH, C., ROBERTSON, J.F., MACMILLAN, D., BLAMEY, R.W., ELLIS, I.O., Int. J. Cancer., 116, nr. 3, 2005, p. 340.

14.ZAHA, D.C., LAZAR, E., LAZUREANU, C., Rom J. Morphol. Embryol., 51, nr. 1, 2010, p. 85.

15.AZOULAY, S., LAE, M., FRENEAUX, P., MERLE, S., AL GHUZLAN, A., CHNECKER, C., ROSTY, C., KLIJANIENKO, J., SIGAL-ZAFRANI, B., SALMON, R., FOURQUET, A., SASTRE-GARAU, X., VINCENT-SALOMON, A., Mod Pathol 18, 2005, p. 1623.

16.QURESHI, H.S., LINDEN, M.D., DIVINE, G., RAJU, U.B., Am. J. Clin. Pathol., 125, nr. 3, 2006, p. 377.

17.KOWALSKI, P.J., RUBIN, M. A., KLEER C. G., Breast Cancer Res., 5, 2003, nr. 6, p. 217.

18.LIU, J.B., FENG, C.Y., DENG, M., GE, D.F., LIU, D.C., MI, J.Q., FENG, X.S., World J. Surg. Oncol., 15, 2017, p. 139.

19.HEIMANN, RUTH, LAN, FUSHENG, MCBRIDE, RUSSELL, HELLMAN, SAMUEL, Cancer Res., 60, 2000, p. 298

20.RAKHA, E.A., EL-SAYED, M.E., GREEN, A.R., LEE, A.H., ROBERTSON, J.F., ELLIS, I.O., CANCER, 109, nr. 1, 2007, p. 25.

21.TANG, D., XU, S., ZHANG, Q., ZHAO, W., Med Oncol, 29, nr. 2, 2012, p. 526.

$\overline{\text { Manuscript received: } 19.10 .2018}$ 